\title{
Revista como observatório de dados acadêmicos
}

\author{
Colaboração Aberta ${ }^{1}$ \\ 23 de Setembro de 2020
}

\begin{abstract}
Resumo
Neste white paper, propomos que dados acadêmicos sejam registrados na forma de artigos, com o objetivo de sistematizar o histórico de propostas e suas reflexões.
\end{abstract}

palavras-chave: artigos científicos, dados acadêmicos, serviço público

A versão mais atualizada deste artigo está disponível em https://osf.io/w96m2/download

\section{Como ser coautor(a) deste artigo?}

1. Envie-nos suas observações e responda às seguintes perguntas.

2. Quais discussões você adicionaria a este artigo?

3. Você encontrou algum erro ou argumento inconsistente? Dê uma justificativa detalhada.

${ }^{1}$ Todos os autores com suas afiliações aparecem no final deste artigo. 


\section{Introdução}

4. As universidades federais brasileiras são financiadas com dinheiro público.

\section{Fórum público}

5. Dado (4), é importante que exista um fórum público para discussões e compartilhamento de experiências e decisões acadêmicas referentes aos dados institucionais das universidades públicas.

6. Este fórum pode ser mediado por meio de uma Revista Científica digital indexada e com ISSN.

\section{Como criar um periódico institucional?}

7. Em [1], o autor apresenta importantes diretrizes sobre como criar um periódico científico do tipo Overlay Journal [1].

8. Um Overlay Journal é um periódico científico mediado por qualquer plataforma digital (ex., Wordpress), cujos artigos são hospedados em um servidor de preprints.

\section{Considerações Finais}

9. Criar um fórum público sobre as atividades das instituições públicas brasileiras oferece maior equidade, transparência, reprodutibilidade, respeito à cidadania, produtividade, além de inúmeros outros benefícios.

10. Em um periódico voltado para este fim, melhores decisões poderão ser tomadas a partir de experiências bem-sucedidas comprovadamente registradas. 


\section{Ciência Aberta}

O arquivo latex para este artigo, juntamente com outros arquivos suplementares, estão disponíveis [2].

\section{Referências}

[1] Lobo, Matheus P. "A Do-it-yourself Overlay Journal." OSF Preprints, 27 June 2019. https://doi .org/10.31219/osf .io/gy8qv

[2] Lobo, Matheus P. "Open Journal of Mathematics and Physics (OJMP)." OSF, 21 Apr. 2020.

https://doi.org/10.17605/osf.io/6hzyp

\section{Colaboração Aberta}

Matheus Pereira Lobo (autor principal,mplobo@uft.edu.br) (1,2 $^{1}$ https://orcid.org/0000-0003-4554-1372

Rosária Helena Ruiz Nakashima ${ }^{1}$

https://orcid.org/0000-0001-7798-6363

${ }^{1}$ Universidade Federal do Tocantins (Brasil)

${ }^{2}$ Universidade Aberta (UAb, Portugal) 